\title{
Hysterical Realism in Don DeLillo's Novels: Death Phobia, Hypochondria and The Revival of Religion
}

\author{
Nader Mostafa Helmy
}

\section{$\underline{\text { Abstract }}$}

The present study aims at proving that the novels of Don DeLillo (1936) belong to the genre of hysterical realism. In White Noise (1985) and Cosmopolis (2003), DeLillo highlights the repercussions of modernist materialism and postmodernist approval of uncertainty, representation over reality and chaos in the American society, and which eventually lead to diminish the spiritual aspect of religion, and magnify materialistic values represented by scientific, technological and medical advances. Hysterical realism in White Noise and Cosmopolis is mainly incarnated in the characters' desperate and absurd attempts to escape their fear of death and to adhere to the mundane life. The study critically tackles the characteristics of hysterical realism, and the common features in the two novels. Two important findings of the study are: DeLillo's severe criticism of the chaotic skeptic world created by embracing postmodern ideals through the conventions of realism but in an absurd way; and DeLillo's implied invitation for the Americans to revive the role of religion in their life, so as to act as a spiritual remedy for the evils caused by the modernist/postmodern principles.

Don DeLillo (1936- ) is a prolific American writer and winner of various awards such as the American National Book Award for White Noise. The classification of DeLillo's fiction is a matter of controversy among critics. Several critics tend to classify and discuss DeLillo's writing under the umbrella of postmodernism. Scott Rettberg, for instance, contends that the work of DeLillo is "distinctly post-modern" (1). Joseph Tabbi in Cognitive Fictions, and Christopher Douglas in "Don DeLillo" also consider the writings of DeLillo postmodern (Tabbi: 2002; Douglas: 2002). Other critics, disagreeing with this assumption, classify the novelist's work as modernist, poststructuralist, or as fitting within "systems theory". For example, Tom LeClair considers DeLillo "a systems theorist" (3), and Frank Lentricchia argues that DeLillo is the "last of the modernists whose subject is the postmodern condition" (14). Notwithstanding these diverse approaches of examining his fiction, the present study is an attempt to prove that DeLillo's fiction belongs to a genre called hysterical realism. White Noise (1985) and Cosmopolis (2003) are apt examples of how hysterical realism operates in DeLillo's fiction. The study underscores DeLillo's severe attack on the hysterical 
atmosphere resulting from modernist materialism and the postmodernist approval of uncertainty and fragmentation. In this sense, the study will shed light on how DeLillo implicitly calls for the return of religion to man's life as redemption and spiritual healing for the evils caused by the chaotic materialistic world.

Although White Noise and Cosmopolis are not usually discussed together, this study analyzed the common features of these novels. The analysis covers four main points: the reasons behind the protagonists' death phobia and hypochondria; the devices, or auras of authority, employed to escape or mitigate their fears; the willfully self-destructive propensity of the protagonists; and the tragicomic end of the two novels.

The term hysterical realism was coined by James Wood in an essay on Zadie Smith's White Teeth, titled "The Smallness of the 'Big' Novel: Human, All Too Inhuman", which appeared in the July 17 $7^{\text {th }}, 2000$ issue of The New Republic. Wood uses the term to refer to a writing style where the author attempts to talk about "a real social phenomenon with funny and strange characters, an odd plot and over elaborate prose. It [hysterical realism] is a form of social commentary meant to both amuse and comment on society" (87). What distinguishes hysterical realist novels from postmodernist ones is the lack of the narrative experimentation. Furthermore, in hysterical realism the plot is developed under the conventions of realism which is overworked. Laura Miller in "The War for the Soul of Literature" points out that the works which fall under hysterical realism are:

full of information, ideas and stylistic riffs; they have eventful plots ...; they experiment with form and voice;... The tragicomic is gentle and sympathetic; it forgives its characters for follies and inconsistencies that are simply part of an inevitable human waywardness and unknowability

According to DeLillo, man's hysterical reality is an inevitable repercussion of surrendering oneself to the incarceration of modernist materialism and/or to the chaotic atmosphere of postmodern world. Modernism assumes an understanding of human self as coherent and autonomous and that man is a thinking being who is capable of rationally perceiving, knowing and conquering the world. Modernism, then, urges man to embrace the power of the scientific rationality to secure a promising future (Hurd). Technology and science, the representatives of 


\section{Nader Mostafa Helmy}

modernist materialism in White Noise and Cosmopolis, will eventually confine humans in a very restricted area of thinking. Postmodernism, on the other hand, undermines modernist values, and instead emphasizes "fragmentations, discontinuities and chaos rather than the order, coherence, and simplicity characterizing the modernist philosophy" (Waugh 66). Postmodernism, moreover, excludes the concept of metanarrative on the ground that no grand theory can encompass the multitudinous sides of human nature; religion is no exception of course. Furthermore, the postmodern denial of the existence of objective realities has made authors like DeLillo concerned with the "vacuity of our age" (Rettberg 2). Simulacrum is thus a natural product of postmodernism as it suggests that man lives in an endless process of copying reality- a copy of a copy- since the original or objective reality is always lacking, as Christopher Douglas puts it, "one of the themes in DeLillo's fiction is the loss of originals", (106). Since the protagonists of White Noise and Cosmopolis frequently suffer a sense of foreboding, they tend to depart themselves from the existing reality, living in a world of their own (simulacrum) as a kind of shelter against what they fear most (mortality). DeLillo, accordingly manipulates a postmodern technique to criticize its impact on humans as the consequences of simulacrum will ultimately lead to an hysterical atmosphere, an atmosphere which permeates most of DeLillo's novels:

The characters in Don DeLillo's novels inhabit a world that is at times cynically hysterical, sometimes loaded with hopes and potential, sometimes with a brooding, stark darkness that is frightening to us because of the fact that it is so present in our everyday lives (Rettberg 1).

What DeLillo recognizes more than postmodernists do is that there must be logic to human existence, a framework that functions as a reference to people when encountering traumatic experiences; religion is a choice in this case.

In an interview, DeLillo describes his characters as real people except that they are "dominated by a sense of invisibility, paranoia and dread. In many respects they are like us, except they live with an unsettling awareness of a world we prefer to ignore" (Passaro 79). In a world dominated by overwhelming materialistic conditions such as callous capitalism, invasive media, terrifying technology and deceptive consumerist values, man is liable to hysterical conditions such as death phobia and hypochondria, diseases from which the protagonists of White 
Noise and Cosmopolis suffer most. The protagonists of these novels "pathetically struggle in a world of indecipherable, de-centered systems. There is no one system that is universally accessible" (Rettberg 1). Man thus urgently needs a spiritual value that could make sense out of his/her life. Religion, with its redemptive, illuminating and healing powers as well as its abiding values, could be the metanarrative employed to alleviate man's hysterical reality. As long as all other metanarratives such as materialism, communism, and capitalism failed to assimilate into human mind and spirit, religion with its spiritual potential which encompasses all human needs could act as the guide to humans in the maddening world. The absence of such a spiritual guide might convert man's entire life into a big mess. Although DeLillo does not explicitly introduce such a proposal in a straightforward manner, one could discern this submission in the margins of the novels in focus.

\section{White Noise}

\section{Jack Gladney: Death Phobia}

Jack Gladney, the protagonist of White Noise, and Eric Packer, the protagonist of Cosmopolis, are early depicted in the two novels as those who are dreadfully preoccupied with their own health. In a world dominated by postmodern hysterical, frantic, outrageous ideals, Jack and Eric, obsessed by their fear of death and sickness, are in a constant search for immortality. Death is accordingly the motif in the two narratives since it shows the many layers in which death appears in almost all areas of our lives: from technology to media, to [consumerism]. This hysterical atmosphere is what constitutes DeLillo's delineation of man's hysterical reality, a reality which disheartens man to find a definition to his life.

White Noise traces the panicky life of Jack Gladney, the professor and the founder of Hitler Studies at Midwestern University and the first person narrator, his wife Babette, and six children from various previous marriages, following an industrial accident that releases toxic insecticide into their neighborhood. Jack is exposed to this toxic insecticide (Nyodene D), and hence his death phobia is reinforced. Along with his wife, Jack endeavors to possess an illegal drug called "Dylar", which is believed to eliminate death phobia. Death phobia distracts Jack from attaining a serene and meaningful life. Hence, the novel is concerned with a very common but rarely discussed issue: death phobia. 


\section{Nader Mostafa Helmy}

The title of DeLillo's novel White Noise, in fact, furthers the argument in this paper as fear of death has become more or less like 'white noise'. 'White noise' is "media noise, the techno-static of a consumer culture that penetrates our homes and our minds with brand-name items and fragments of TV and radio talk shows" (Tew 33). Heinrich, Jack's son, talking with his father, accentuates the same point, "the real issue is the kind of radiation that surrounds us every day. Your radio, your TV, your microwave oven, your power lines just outside the door, your radar speed-trap on the highway. For years they told us these low doses weren't dangerous" (174). Babette, too, refers to the same point in her conversation with Jack, "what if death is nothing but sound? ... Electrical noise" (198). In other words, the implications of the title are closely related to the frightening materialistic forces which severely impinge on the Gladney family such as mass media, technology, and false consumerist values. Such forces are deliberately adopted and driven to extremes in the Gladney household to stamp out their fear of death. However, the outcome of their attempts is disenchantment and hysteria.

The mood of White Noise is thus hysterical. The tragicomic atmosphere of hysterical realism is early incarnated in the novel through the conversation between Jack and Babette on expressing their mutual desire to die first since each one cannot bear life without the other partner. In fact, both Jack and Babette are trying to mislead each other as Jack admits to himself that, in truth, he would choose loneliness over death. It is much more like hallucination about the present which is excruciating. The debate between Jack and Babette over who will die first becomes childish and hence comic.

What adds fuel to Jack's anxiety about his fear of death is his wife's affirmation that she is terrified of the idea that she may die too, "I'm afraid to die...I think about it all of the time... it haunts me Jack, I can't get it off my mind" (186-87). Jack now realizes that it is not only him who is concerned with his mortal fate. As long as there are others who share with him the same feeling, his phobia is enhanced and hence justified. However, Jack's response to his wife's fears is humorous, "that's what I can't forgive you for. Tell me you're not the woman I believed you were. I'm hurt, I'm devastated" (197). If Jack is not willing to forgive his wife for her concern with death, he should provide her with the role model that can help her transcend such fears. On the contrary, he laments his fortune and hence deepens her agony, "[t]he deepest regret is death. The only thing to face is death. This is all I think about. There's only one issue here, I want to live" (270). 
Paradoxically, however, none of the protagonists actually dies. Actual death does occur, but only "at the fringes of the story" (Boxall 88). One of the schemes they adopted to mitigate their fears is to accompany people who enjoy unawareness about their mortality. That is why Jack and Babette spend much time with their youngest son, Wilder, who "doesn't know he's going to die. He doesn't know death at all. ... How lucky he is. A cloud of unknowing, an omnipotent little person. The child is everything, the adult nothing" (189).

In White Noise, DeLillo is adept enough to provide jack with foils who refute his strategies of escaping death. Orest, one of these foils, is introduced as an opposite figure to Jack as he is the only character in the narrative to be valiant enough to confront death by sitting in a cage, which is full of deadly snakes, for the maximum time in order to beat a new record. When Orest says, "[t]hey want to bite, they bite. At least I go right way" (198), he simply wants to convey to Jack and the reader an important message about death: death is inescapable but it can be transcended. Orest, in fact, does not want to die; rather he is willing to prove to himself and to others that although death lurks everywhere, it should not affect people's willingness to enjoy life. In a moment of enlightenment, Jack reveals to Babette the same recognition about death, "we have these deep terrible lingering fears about ourselves and the people we love. Yet we walk around, talk to people, eat and drink. We manage to function. The feelings are deep and real. Shouldn't they paralyze us?" (198) This recognition does not however give any relief to Jack simply because the outer world is still dense with postmodern and modernist deteriorating ideals which collaborate to undermine the spiritual potential of religion. In this respect, Jesse Kavadlo, aggressively censuring the postmodern world, comments:

Dominated by the forces of late capitalism, postmodern society is characterized by globalization, pervasive consumerist values, a preoccupation with spectacle and images generated by the media, and technological growth. These elements would seem to combine to diminish the influence of religion on the lives of people (15).

Kavadlo further condemns modernity for the same reason: discarding religion from man's life:

Modernity, with its humanist orientation and its preoccupation with the present and the material, has 
alienated man from the awareness of his own mortality and, more importantly, dissociated death from the religious realm. Man is hence severed from the spiritual consolations offered by religious explanations of death (ibid 17).

DeLillo's characters' deafness to any sensible voice leads them to their own destruction. Interestingly enough, Jack early in the novel states that "all plots tend to move deathward" (18). The plots, Jack refers to, are the materialistic world webs which offer man no shelter or security, and as a result they ruin his life. An important aspect of hysterical realism is thus the characters' awareness of the destructiveness of their deeds and the lack of knowledge about the root causes of their anguish. In order to foster his point of view, DeLillo presents manifestations of both modernist materialism and postmodernist uncertainty in 1980's and late 1990's America: science \& technology, consumerism, and mass media. In fact, these forces among others are embraced by the protagonists in White Noise and Cosmopolis as auras of authority in the hope that they will provide them with security as well as protection against their ultimate trepidation, death.

\section{Auras of Authority [Simulacra]}

\section{Mythic Figures: Hitler}

Early in the novel Jack Gladney introduces himself to us saying, "I am chairman of the department of Hitler studies at the College-on-the-Hill. I invented Hitler studies in North America in March of 1968" (4). Hence, from the very beginning of the novel Jack adopts the character of Adolf Hitler as a "shield" against death. In fact, there are several reasons for selecting Hitler as a refuge against death. First, Jack cherishes the idea that Hitler is a character that enjoys a powerful aura of authority. Such a belief is the reason behind naming his elder son Heinrich. Heinrich is a German name which Jack believes "it had an authority that might cling to [Heinrich] ... [He] wanted to shield [Heinrich], make him unafraid" (63). Second, the character of Hitler is still "a mystery to most people" as he is "full of evil, hatred, and [has] capacity for death" (Hunsinger, "Heinrich's Hidden Prophesy"). Third, Jack believes that Hitler gains more powerful authority from the crowds [his supporters and followers] that surround him. Accordingly, Jack clings to the idea that crowds are a way to "keep out death. To break off from the crowd is to risk death as an individual" (73). Like Hitler, Jack entrenches himself into crowds all the time. He enjoys the crowds in the supermarket. At work, he surrounds himself with 
his students who, he believes, share with him the same sense of fear. Ironically, in this particular case it is the 'leader' more than the crowd who fears death (Osteen 169). When Jack and his family have to evacuate because of the toxic spill, it is the feeling of being part of a larger group of people which alleviates his fears:

The place was crowded, still quite cold, but the sight of nurses and volunteer workers made us feel the children were safe, and the presence of other stranded souls, young women with infants, old and infirm people, gave us a certain staunchness and will (129).

Murray, acting as the narrator's spokesman, comments on Jack's futile attempts to hide behind the "mythic" figure of Hitler, "helpless and fearful people are drawn to magical figures, mythic figures, epic men who intimidate and darkly loom. ... You're talking about Hitler, I take it. ... Some people are larger than life. Hitler is larger than death. You thought he would protect you. I understand completely" (287). Murray thus sums up Jack's quandary by stressing the vainness of the simulated reality Jack has created for himself: Hitler is a mortal being after all.

\section{Science}

Being disappointed in Hitler as a shield against death, Jack turns to another aura of authority, science. The modernist view of the potential of science is overtly questioned in White Noise. Babette has slept with Willie Mink, a pharmaceutical company manager, as a bargain to obtain the drug "Dylar". Babette, in fact, acts as a guinea pig to test the validity of the drug to eliminate the symptoms of death phobia. Such an experiment enhances the idea that death phobia is widely spread in the American society, and Jack is not therefore an exception in his exaggerated fears. Having discovered Babette's infidelity, Jack's main interest is not to avenge himself, but to obtain the drug. Despite being informed that Dylar does not cure or reduce the symptoms of death phobia, Jack becomes more and more obsessed with the idea that a couple of pills could put an end to his agony. Jack, therefore, puts his trust in science even if it will not actually give him any practical solutions to his problems. The powerful potential of science, moreover, leads people like Jack to believe that "if something can be measured, it can be explained. If it can be explained, it can be controlled" (Rettberg 2). Jack's determination to obtain Dylar by any means turns out to be a desperate search for the aura of fearlessness that science and technology may 


\section{Nader Mostafa Helmy}

provide. Murray gives utterance to this idea when he informs Jack that science "creates an appetite for immortality on the one hand. It threatens universal extinction on the other. Science is lust removed from nature" (285). Murray's visionary comes true when the enticements of Dylar eventually prompt Jack to kill Mink in order to obtain the drug. Dylar, the product of science in the novel, has become an impetus for suicidal acts.

In White Noise, Dylar is intended to eliminate the symptoms of death phobia; while, in reality, it enhances it. DeLillo consequently underscores the point that advances in science and technology could exaggerate man's concerns with his mortality. Winnie, a professor of chemistry, believes that man needs to fear death, as it gives life a boundary. She advises Jack not to follow the so-called magical effects of Dylar. Instead, he needs to take matters as they come. This destiny-based opinion is further supported by Murray who states that if science fails to satisfy man's spiritual needs about life and death, religion may redeem man's spirit by believing in the resurrected souls. Again, DeLillo obviously calls for the revival of the role of religion as redemption for man's inclination to the illusory prospects of science and technology. In this regard, Louise Wilson contends that "the inevitable outcome of this technoscientific development is a renewed need for the idea of God" (45).

\section{Consumerism: The Supermarket}

Consumerism is a significant characteristic of capitalist societies, being closely associated to modernity. In White Noise, consumerism is dealt with as an escapist device adopted by the characters in order to avoid their fear of death. The supermarket, the symbol of consumerism in the novel, is the place where people gather in large groups to buy stuff whether they need it or not, just to cherish the feeling that they are still alive. Jack explains this idea:

I shopped for its own sake, looking and touching, inspecting merchandise I had no intention of buying, then buying it. . . I began to grow in value and self-regard. I filled myself out, found new aspects of myself, located a person I'd forgotten existed (83).

To shop is therefore to define one's identity. People who are disturbed by their own fears need to be esteemed in order to regain self-confidence. Hence, Jack spends more and more money in order to enjoy selfconfidence and that he is still attached to the world he is afraid to depart, 
"Here [in the supermarket] we don't die, we shop" (38). Osteen observes that "consuming attaches persons to the things whose reproducibility betokens immortality" (171), and hence the consumer becomes a cog in the capitalist machine. Since Jack's fear of death is intensified in time of loneliness, Jack attaches himself to the supermarket so as to bridge the spiritual gap resulting from such feeling. Paradoxically, however, excessive shopping does not give Jack and Babette a real sense of reassurance as the ecstasy they feel while shopping fades away as soon as they leave the supermarket. Shopping, moreover, diminishes the familial bonds as the Gladneys keep silent in their way home, "We drove home in silence. We went to our respective rooms, wishing to be alone" (84). Consumerism therefore fails as an aura of authority to give any real relief to Jack's fear of death as Wilson explains:

We will all die, just as the sunset and the shopping experience come to an end. Buying things will not help, for it is a vain attempt to master a system that is already decided by technology and deathly waves (41).

Attaching oneself to mundane transient objects will not recompense for the traumatic spiritual gap deepened by capitalist ideals. The more the people endeavor to shop, the more they get attached to the things they buy. The inevitable consequence of such attachment is more devotion to life and more denial of death.

\section{Media}

DeLillo's questioning of the postmodern emphasis on uncertainty, chaos and the denial of objective realities is presented through the role of mass media in modern societies. All members in the Gladney household depend entirely on the media, particularly the television and the radio, as the authentic source of information. Whenever they debate over any issue, they resort to what TV says to support their point of view. To highlight the significance of TV in the Gladneys' life, DeLillo writes, "If our complaints have a focal point, it would have to be the TV set, where the outer torment lurks, causing fears and secret desires" (80-81). By embracing the reality of the media, the Gladneys lose confidence even in their sensations and gradually abandon their own true experiences. Having failed to recognize that the television has the ability to manipulate images, the Gladneys start to live in what Baudrillard calls "media simulacra" which result in creating a new reality to the people who perceive and believe in it. Therefore, the media, believed to mirror reality, 
is interpreted by Baudrillard as itself "hyperreality" whose "images, signs and codes, simulate an autonomous realm in everyday life" (qtd. in Linardi 237).

The absence of objective realities in the characters' lives in White Noise results in a huge cloud of uncertainty that covers all aspects of life. Postmodernism nurtures the idea that reality is representational and that everyone has his/her own codes to interpret the surrounding phenomena in their own ways. DeLillo does not entirely reject this idea. He rather interrogates the excessive practice of this theory that could eventually eradicate all objective realities from man' life. The ultimate consequence of the absence of objective realities and the supremacy of representation is an extremely blurred atmosphere which will ultimately lead to a state of incertitude. An apt example of such incertitude is when Heinrich tells Jack that the radio said it was going to rain tonight, while Jack points out that it is already raining, and that they do not need to believe the radio over their own senses. Although Jack tries his best to convince his son that it is already raining, Heinrich gives credibility to what the weather meteorologists say in the radio that it is going to rain. Having failed to convince his son, Jack gives in, "First-rate, I told him. A victory for uncertainty, randomness and chaos" (23). By giving the meteorologists an aura of authority and credibility even if the objective reality is quite plain, DeLillo mocks the postmodern inclination to representation and uncertainty over the incontestable realties.

In their endeavor to assimilate into the media reality, the characters in White Noise try to respond according to what the media broadcasts. During the evacuation, Steffie, Jack's daughter, adjusts her physical response to the symptoms broadcast on the radio. When the radio says the "airborne toxic event" causes nausea, she pretends she has nausea. Then she complains of sweaty palms when the radio assures that sweaty palms are the real symptoms of the "airborne toxic event." Steffie therefore bestows credibility on the radio even if it gives different, may be opposing realities of the same situation. In reality, Steffie does not suffer from any symptoms of the "airborne toxic event", but because she no longer trusts her own sensations she prefers to go after an aura of authority that could interpret reality on behalf of her sensations. Herein lies the destructiveness of the postmodern media reality as Kathleen LeBesco points out, "DeLillo explores the potential consequences of such a blind assignment to [media simulacrum] and the consequences it might have of confusing what is real and what is representation, resulting in a 
hyperreality" (92). The priority of representation over the original is therefore humorously satirized in White Noise.

Since Jack and Babette are haunted by death phobia, they wittingly seek a different reality that could diminish their concerns. The reliance on TV shows and movies is thus vindicated. For Jack and Babette, TV becomes the "distancing device between them and their own mortality" (Rettberg 7). On TV, Jack and Babette are indulging in the simulated realities provided by action movies in which heroes survive at the end despite all the deadly circumstances they have gone through. However, media with all its powerful potential does not really help Jack to realize the inevitable end of all humans. Instead of enlightening people about the nature of spiritual matters like death, media engenders a sense of hysterical adherence to life.

\section{Self-Destructiveness}

When Jack reveals to Murray, early in the novel, that "all plots move deathward", he anticipates what he is going to do by the end of his quest for eternity. Being disappointed in all the auras of authority [or plots] that could terminate his fear of death, Jack wages a war against the modernist/postmodernist evils by determining to kill Willie Mink who is supposed to be the origin of his suffering. For Jack, Mink represents both modernist materialism, for his reliance on drug technology, and postmodernist chaotic uncertain atmosphere, for the confusing and hysterical side effects the Dylar produces. Accordingly, the confrontation between Jack and Mink turns out to be a confrontation between modernist/postmodernist ideals and the hysterical reality, a byproduct of both which Jack represents. Urged by Murray's opinion that in the process of killing a new life is gained, "to kill him is to gain life-credit. The more people you kill, the more credit you store up" (290), and equipped with the fire gun provided by his father-in- law, Jack enters Mr. Mink's hotel room with a determination to kill him.

Hysterical realism is highly expressed in the confrontation between Jack and Mink as the most violent scene in the novel turns out to be the most hilarious one. Babette told Jack before that one side effect of Dylar is that one could confuse language with reality, i.e. the mistaking of a word for its content. Jack exploits this poststructuralist concept when attacking Mink. It is enough for Jack to tell Mink words like, "hail of bullets" to find him "hitting the floor... showing real terror" (311). The postmodern world will eventually result in the characters' incapability to distinguish between "signifier and signified" (Linardi 239). 


\section{Nader Mostafa Helmy}

Finally, Jack turns from theory to practice and shoots Mink twice in the stomach, and then puts the gun in Mink's hand to make it like a suicide. Jack's triumph over the modernist/postmodernist world does not however last long as Mink defends himself by shooting Jack in the wrist. Jack's belief that killing can be "life-affirming" is then fallacious because killing fails too to provide him with any sense of assurance or security. DeLillo, however, "does not condemn Jack, nor does he downplay what has happened" (ibid) as he simply shows us "how far into postmodern ambivalence Jack has descended, so that his crime, which does not even have negative consequences for Jack, illustrates the stage of his postmodernization" (ibid). A distinct feature of hysterical realistic fiction is, therefore, forgiving the characters' ill deeds simply because these characters are presented as victims of the hysterical, cruel circumstances surrounding them. After shooting Mink, Jack regrets his deed and finds that Mink is just another victim of the chaotic society they live in, "I looked at him. Alive.... I felt I was seeing him for the first time as a person. The old human muddles and quirks were set flowing again. Compassion, remorse, mercy" (313). Jack therefore comes to view Mink as just another frightened man whose use of Dylar is evidence of the same fragile condition that Jack possesses himself. Jack's recognition is embodied in his decision to save Mink's life by taking him to the nuns for medical attention.

When Jack arrives in the hospital to save Mink's life, he is shocked to find that even the Catholic German nuns who run the hospital pretend to believe in God as they do not really have any real faith. One of the nuns justifies their pretension saying, "if we don't pretend to believe these things, the world would collapse" (318). Although the nuns are aware of the postmodern skeptical world, they are trapped into that world themselves, and hence they come to be victimized by the same postmodern chaotic world. To believe that their pretension will save the world, the nuns are deluded as people like Jack have already collapsed due to the absence of adequate spiritual knowledge about life and death. Religion teaches people how to perceive death as far as how to live their own lives. The absence of religion in the mechanically technological world gets people involved in a desperate search for immortality. DeLillo is quite aware that having real faith is what maintains the world from being collapsed. DeLillo also rebuffs the idea that faith is only restricted to a 'minority' (the nuns) who, on behalf of other people, takes the responsibility of saving the world through their simulated faith. False faith thus makes Jack quite appalled as it should be the only thing not to 
be simulated. Faith is the only beam of hope remained to Jack and the loss of faith means the loss of hope to recapture a peaceful life.

\section{Cosmopolis}

\section{Eric Packer: Hypochondria}

Eric Packer's universe, like that of Jack Gladney, is "a resolutely postmodern media-saturated world of decadent self-referential capitalism, consumerism and failing metanarratives" (Smith 240). In Cosmopolis DeLillo gives us one day in the life of Eric Packer, a currency trader and a multi-billionaire. The reader accompanies Eric in his ride from his deluxe apartment in Manhattan to the west side of New York in order to have a "haircut". Eric is seated most of the time in his high-tech limousine, from which other characters and events are introduced. Eric's journey is critically seen as "a metaphor for the volatile movements of [finance] capital seeking to exploit evanescent differences in interest rates, currency values and stock prices on the global markets" (Conte 181). Cosmopolis' Eric is the embodiment of the late 1990's stock market moguls who lives in the virtual world of figures and images. His job is to gamble on currencies in the stock market. Accordingly, he lives in a world where money brings more and more money, and where fortunes could be lost in a couple of hours.

The hysteria which overwhelms the stock market in general and the currency rates in particular is what makes DeLillo admit, in an interview with Paul Gediman, that the events of Cosmopolis "occur in an exaggerated reality" ("A Day in the life of the Present" 7). As suggested by the title, Cosmopolis is set in a hyper-capitalist society. The title of the novel, like that of White Noise, furthers the implications of the hysterical atmosphere of the novel as well as the protagonists' sense of hypochondria, as Aaron Chandler suggests, "Don DeLillo depicts New York as a microcosm for neo-liberal globalization and its problems. He conceives the city portrayed in a state of chaos, suffering from collective posttraumatic stress disorder" (248).

Just like Jack Gladney, Eric Packer is preoccupied with his own health. His mania to protect himself from any minor disease leads him to experience a sense of hypochondria. A person with hypochondria continues thinking he is seriously ill although appropriate medical evaluations and reassurances show that his health is fine ("What is Hypochondria?") Just as death phobia spoils Jack and Babette's life, hypochondria does the same with Eric but on a larger scale. 
Metaphorically, Eric's life, like the stock market, is subject to danger in any moment and hence his entire life has become hysterical. Patients with hypochondria are not aware that "depression and anxiety produce their own physical symptoms that might be mistaken for signs of a serious medical disease" ("What is Hypochondria?"). Eric is early introduced in the novel as an individual who is unable to sleep due to exhaustion and tension, "sleep failed him more often now, not once or twice a week but four times, five" (5). Eric's insomnia can be interpreted as a consequence of his obsession of surveillance both of his bodily functions as well as of his financial investments to the extent that he is not willing to take a nap lest he may be liable to either physical disorder or financial loss, as Christopher Donovan explains "currency markets never close. And the Nikkei runs all day and night now. All the major exchanges. Seven days a week" (36). Eric's sleeplessness is accordingly a result of the hysterical world he himself contributes to exaggerate its devastating impact on individuals.

Experiencing a feeling of apprehension, Eric, in his limousine, is watched by a nurse and two armed guards. In addition, Eric's bodily functions are monitored on screens which are placed close to the stock market screens. DeLillo, accordingly, draws a parallel relationship between Eric's life and the stock market. Any decline in the stock market will inevitably lead to deterioration of Eric's health. To emphasize this parallelism, the language used to describe the market data on the screens is the same one used to describe a patient's bodily functions in an intensive care unit, "polychrome numbers pulsing" and "the numbers glide horizontally and the bar charts pump up and down" (39).

One aspect of hysterical realistic fiction is crystallized in Eric's persistence on ludicrously searching for unnecessary meanings and interpretations for trivial matters such as "asymmetrical prostate" or 'sneezing': "He realized that he always sneezed twice, or so it seemed in retrospect. He waited and it came, rewardingly, the second sneeze. What causes people to sneeze?" (140). Similarly, Eric is trying to find a reason for the rise of the Yen. Eric who gambles on the decline of the Yen rate in the stock market cannot alienate himself from his body or from the stock market. Eric is accordingly leading the same hysterical life John suffers from in White Noise.

Although Eric is an embodiment of modern individuals who are not at ease with the harsh capitalist systems, his devices to protect himself from mortality are ridiculous and absurd. Eric delusively assumes he is 
invulnerable to death due to his safety measures: his bodyguards, the company of doctors and nurses in his journey, and his bank of information supported by his computers. However, he closes the eyes to the unpredictability of death exactly as he ignores the unpredictability of currency rates. Vija Kinski, Eric's chief of theory, ironically commenting on Eric's silly dream of mortality, tells him, "People will not die. Isn't this the creed of the new culture? People will be absorbed in streams of information" (85). Kinski, moreover, asserts the submission that man loses control over the financial systems he himself has created. Man accordingly deals with uncontrollable systems that lead to a state of hysteria that permeates people's life:

In the end you're dealing with a system that's out of control. Hysteria at high speeds, day to day, minute to minute . . We create our own frenzy, our own mass convulsions, driven by thinking machines that we have no final authority over" (85).

Kinski's words undermine the postmodern chaotic atmosphere of New York, which in turn represents the mood of the entire world. The stock market along with its maniac implications fosters the hysterical ambiance of the modern world, leaving average people in great depression. The protestors' assault on the headquarters is therefore an assault against the oppressive capitalist systems that favor minorities and victimize the majority. Like Winnie in White Noise, Kinski is DeLillo's voice and Eric's foil in Cosmopolis. One of her illuminating comments is the one relating to the demonstration, "this is a protest against the future. They want to hold off the future. They want to normalize it, keep it from overwhelming the present" (91). She predicts earlier that something is going to happen soon to "correct the acceleration of time. Bring nature back to normal" (79). In this way, Kinski presupposes Eric's death, which in turn indicates the vulnerability of the capitalist systems.

Like Jack, Eric needs to be enlightened about the mortality of humans. Kinski, jogging Eric's memory of the hopelessness of the powerful men's absurd dream of mortality, says, "Great men historically expected to live forever even as they supervised construction of their massive tombs on the far bank of the river, the west bank, where the sun goes down" (105). Despite Kinski's admonition, Eric tragically aspires to the future [the decline of Yen] which, he believes, will sustain him with eternity [wealth]. Eric's deafness to the voice of wisdom and his blindness to the indisputable truth of death predetermine his willfully self-destruction. 


\section{Nader Mostafa Helmy}

This, in fact, echoes Jack Gladney's statement that "all plots go deathward". All the plots Eric hunts for to shield himself against death will eventually lead to a catastrophe. Jack, therefore, sacrifices his present for the sake of the uncertain prospects of the future, as DeLillo comments:

The idea is time. ... Money makes time.... Clock time accelerated the rise of capitalism. People stopped thinking about eternity. They began to concentrate on hours, measurable hours, man-hours, using labor more efficiently (79).

Kinski, opposing Eric's futuristic orientation, believes that people like Eric delusively cling to the idea that "the future is always a wholeness, a sameness. [They] are all tall and happy there...This is why the future fails. It always fails. It can never be the cruel happy place we want to make it" (91). Pursuing future makes people distance themselves from their present reality and embrace delusive future promises. In Cosmopolis, fearing death is therefore a product of man's excessive leaning to the future.

In his first encounter with pain, Eric comes full circle to his mortality, "As his doctor probes his prostate, Eric experiences pain. There was pain, probably just muscles tensing....But it hurt. It was pain. It traveled the circuitry of nerve cells" (47). Pain makes Eric more conscious about his mortal body as it erodes his sense of invulnerability to death. Despite the pain being a momentary experience, Eric experiences what Elaine Scarry calls "the unmaking of the world through pain" (30). Having recognized his mortal body through pain, Eric resorts to the same auras of authorities Jack Gladney embraces in White Noise in an attempt to shun his fears.

\section{Auras of Authority [Simulacra]}

\section{Consumerism: The Limousine}

DeLillo presents the limo as the symbol of lavish, luxurious materialistic realm of the rich, "the limo is simultaneously a bar, a bathroom, a kitchen, a dining room, a security surveillance center, and a doctor's office" (22). The limo is accordingly regarded as a "site of various modes of consumption" (22). It is also equipped with screens which enable Eric to trade in currencies as well as to monitor his bodily 
functions. It consequently represents a microcosmic life (a simulated one) in which Eric feels secure.

DeLillo questions the value of the car whether to be a means of transportation or a place where man could define his identity, "The limousine isolates and separates Packer from the average American. It says to the public, I am rich" (22). The limo, like the supermarket in White Noise, is a place where a person feels he is still alive and consequently his individuality is remarkably distinct. David Gartman contends that everyone tried "to find fulfillment through commodities", which bespoke their individuality (183). Gartman further asserts that this trait "became manifest domestically in automotive consumption" (Ibid). Eric's attachment to his limo is thus an attachment to his identity and to his own life. To be seated in his limo from the very beginning of the story till the very end is a deliberate choice to avoid threats by encapsulating himself (Jack) in the securing realm of his own car. Therefore, the very moment Eric leaves it at the end of the novel to go to his apartment, he faces death when Richard Sheets (who wants to be known as Benno Levin) shoots him. The limo, like the supermarket in White Noise, gives Eric a momentary experience of reassurance; once he leaves it, he is liable to real threats.

\section{Technology}

The limousine is also a symbol of modern technology. By relying on his limo as a source of power that protects him from death, Eric discards the notion of God who is supposed to be man's safe haven in the exasperating world. Modernism maintains that rationalism is man's means to obtain "material security" and thus modernism adopts "the extravagant expectation that technology and science would further not only the control of the forces of nature but also the understanding of self and world" (Kaplan 5). However, in an article entitled "In the Ruins of the Future", DeLillo stresses the deceptiveness of technology:

Technology is our fate, our truth. It is what we mean when we call ourselves the only superpower on the planet. The materials and methods we devise make it possible for us to claim our future. We don't have to depend on God or the prophets or other astonishments. We are the astonishment. The miracle is what we ourselves produce (36). 


\section{Nader Mostafa Helmy}

DeLillo satirically condemns the materialistic aspect of modernism which obliterates the spiritual perspectives from humans' life. Technology makes man believe he is the master of the universe and that he could hold off all possible threats. Eric's own god is his limo in which he isolates himself from the outer world. The limo along with its hi-tech equipments compels Eric to falsely believe he is immortal.

\section{The Stock Market}

In Cosmopolis, Eric relies heavily on the stock market as a source of power. However, Eric's fatal error is that he is trying his best to give an explanation to the unexpected rise of the Yen relying on the flow of information and other conveniences offered by his limo. For Eric, there should be a theory to "explain the yen" (63); a theory which is "latent in nature itself, a leap of pictorial language that went beyond the standard models of technical analysis and out-predicted even the arcane charting of his own followers in the field" (63). Hypochondriac people's belief that every minor phenomenon needs to be precisely interpreted is the origin of their suffering. Eric does not take things as they come simply because he trusts his aptitude to decipher all codes of life. Eric as a modernist who lives in the chaotic world of postmodernism uses his calculations and equations in order to put a frame or a rule through which he could predict the rate of the Yen. However, Eric's visionary faculties cannot help him to correctly expect the rate of the Yen, and hence he is going to lose all his fortune in a couple of hours. The stock market in Cosmopolis is a symbol of the harsh capitalist system man has invented and then lost power to control its ferocity. The stock market, like the figure of Hitler in White Noise, does not provide Eric with any sense of security; on the contrary, it accelerates Eric's movement towards his self-destruction.

\section{Media}

While Jack depends on the images of the television to construct and interpret his reality, Eric depends more on the images of his personal computers. What distinguishes Cosmopolis is that the images of the computer screens rely more on the language of digits and charts. Reality for Eric turns out to be a "virtual space contained in the computer screens" (20), upon which he observes "flowing symbols and alpine charts, the polychrome numbers pulsing" (13), where "the electronic impulses, representing money moving worldwide, possess a life of their 
own" (Smith 244). The digital world therefore replaces the real world and this in turn opens the door to another type of simulacrum.

Eric is an embodiment of those who blindly trust the media particularly the one which is related to digits. His reliance on the digital world makes him deny the linguistic communication with others. For Eric, language is currently "incapable and utterly inappropriate for expressing the current situation, a situation that is marked by simulation, hyper-reality and ever-increasing speeds of change" (Noble 63). Or as Baudrillard puts it, 'the cool universe of digitality has absorbed the world of metaphor and metonymy' (qtd. in Noble 64). It is not surprising then that Eric isolates himself from others by sitting most of the time in his limousine. This, in fact, has its own repercussions on his marital life: he does not often meet his wife. Ironically, he accidentally meets her twice on his journey to have a haircut. DeLillo, therefore, draws our attention to a serious social problem resulting from the omnipresence of the media in every household: it ruins the familial communication and intimacy.

Just as the characters in White Noise prefer the representation of reality to the reality itself, so does Eric in Cosmopolis. One example is the demonstration which takes place near Eric. Although he can follow it through the window of his limousine, he prefers to watch the event on the screen of his TV because "it makes more sense" (89). Eric therefore prefers the representation of the event to the event itself. Hence, DeLillo mocks the triumph of representation over reality.

Unlike Jack, Eric's entire life is mainly based on the simulated world of media. In Cosmopolis, the motif of death phobia is more omnipresent in the media. The screens placed inside Eric's limo exhibit images and data transmitted live from other countries. The director of the International Monetary Fund is shot while appearing live on TV, and the owner of Russia's largest media corporation was also killed in the same way. Eric greedily believes that with the killing of the Russian magnate, he may easily take his place to extend his business to Russia. However, Eric is unaware that these deaths abroad anticipate his death at home. This recognition makes Eric more cognizant about what awaits him at the end of his journey, "at the brink of night that spoke to him most surely about some principle of fate he'd always known would come clear in time" (107). Having recognized his inescapable fate, Eric, like Jack, hastens his own destruction. 


\section{Self-Destructiveness}

Eric's insistence on wrongly gambling on the yen despite his councils' advice to retreat indicates his premeditated movement toward his own destruction by losing all his fortune. In order to pursue his death, Eric first steals his wife's fortune by hacking into her bank account, then moves on to get rid of his security guard by shooting him without any reason. This willfully self-destructive behavior is hinted at early in the novel when Kinski suggests that Eric's death can only occur "because [he] permits it...as a way to re-emphasize the idea we all live under...enforced destruction [so that] new markets [can be] claimed" (92). Even Eric's desire to have a haircut implies his endeavor for his own destruction for the term "haircut" is a slang term meaning "losing enormous sums of money in the stock market" (Crosthwaite 4).

Having realized that he is going to lose his fortune, Eric decides to end his life, since money for Eric is what protects him from death. When Eric says, "the logical extension of a business is murder", he is quite aware of the poetic justice he deserves for his ill deeds. Eric endeavors to amass a fortune by paying no attention to those who are badly influenced by his greedy behavior. Richard Sheets, or Benno Levin, one of Eric's victims in the stock market, avenges himself by killing Eric at the end of the novel. Ironically, however, it is Eric who takes the initiative to shoot himself in his right hand. Accordingly, Eric's willful pursue of his own destruction seems absurd and comic; a feature which typifies hysterical realistic fiction as Emory Elliott suggests, "rather than a symbol or stereotype of the worst of cyber age robber barons, Eric is a comic figure, a spoiled bully who is out of control, self-destructive, and is begging to be punished- a child who needs limits" (23).

Having recognized the impossibility of immortality by clinging to the technological realm of information and digits, Eric surrenders himself to death. Although Eric's deed is suicidal, it is also moral. In fact, the transition from ignorance to recognition is exhibited in Eric's attempts to put a tragic end to his life. In other words, Eric sees his death a necessity to metaphorically demolish the capitalist system he is a part of, and to reestablish a new equal system instead. The retribution of Eric is important for both the narrative and for the cosmic balance, as Benno Levin suggests:

You [Eric] need to die no matter what ... You have to die for how you think and act. For your apartment and what 
you paid for it. For your daily medical checkups. ... For how much you had and how much you lost, equally. ... For the limousine that displaces the air that people need to breathe in Bangladesh. ... The thoughts you have" (203).

Eric's own death signifies the defeat of the harsh capitalist ideals as well as the virtual worlds nurtured by them. By letting himself easily killed by Benno Levin, Eric disconnects and liberates himself from the maddening world, from the oppressive capitalist system, and from his egoistic self.

Although not discussed together, White Noise and Cosmopolis have many points in common. Both novels belong to hysterical realistic fiction which are dense with characters with strange names, a plenty of plots and subplots, and complex ideas. The events of the novels move in a linear fashion. There are no fragments or discontinuities, and the two narratives have unity and wholeness which are collectively uncharacteristic features of modernist and postmodern texts. The two novels use the traditional elements of realism in such a way that the aesthetic principles of realism are, in effect, destabilized through an extreme emphasis on interconnectedness of plot and subplot rather than depth of characterization. Hence, hysterical realist fiction tends to introduce flat characters who can be replaced by ideas.

The protagonists are obsessed with their mortality. Although Jack and Eric do everything they can manage in order to avoid death, they move faster and closer towards their self-destruction. Both Jack and Eric fail to grasp the destructiveness of modernism and postmodernism. As a result, they are depicted as out-of-control characters who desperately endeavor to ward off death. In decisive situations, they behave hilariously and weirdly simply because they are not equipped to deal with mystical matters like that of death. The ultimate outcome of the characters' imprudence and eccentricity as well as the gravity and destructiveness of the modernistic/postmodern problems is a hysterically realistic atmosphere which pervades DeLillo's fiction.

Although White Noise and Cosmopolis have points in common, they also exhibit differences. While Jack tries to escape death by joining the crowds, Eric feels secure in his solitariness. While Jack shares his agony with his wife, Eric occasionally sees his wife on the street. While time in White Noise extends for one year, time in Cosmopolis is compressed as it lasts for a few hours. Most important is that Eric fears death and dies by the end of the story, whereas Jack fears death but does not die. The reason 


\section{Nader Mostafa Helmy}

behind such distinct ends is that Eric is a representative of the system that horrifies and objectifies average people like Jack. Hence, the killing of Eric is a deliberate choice by DeLillo to terminate what Eric represents: oppressive capitalism, invincible civilizations, and decadent communities.

In White Noise and Cosmopolis, hysterical realism is introduced when the characters are no longer able to distinguish between what is real and what is simulacrum. Even DeLillo's readers cannot distinguish between the oppressors and the oppressed; the powerful and the powerless; and the murderers and the murdered. In a world where uncertainty prevails, man leads a very baffling life which summons all kinds of fear such as death phobia and hypochondria. The protagonists of the two novels, out of fear, exhibit conflicting reactions such as gravity and hilarity. Despairingly, they cling to auras of authority such as science, technology, and media in order to escape their fears. However, DeLillo has proved that such auras cannot mitigate human instinct fears; rather, they have deepened man's predicament. DeLillo's protagonists are accordingly deprived from attaining a definition to their identity since they live in a simulated world where access to objective realities is always denied. Although some critics assume that DeLillo does not provide solutions to the issues he raises in his work, this study shows that he frequently underscores the significance of religion as a remedy for the problems raised in the narrative. What DeLillo calls for is not a traditional concept of religion; but a renewed one which could cope with our complicated reality. The absence of religious belief exaggerates the impact of the hysterical reality, which in turn leads to a lack of vision and uncertainty. Because it is the writer's job to see what others cannot, DeLillo is quite alert that the Americans' immoderation in self-protectiveness, their reliance on the simulated realities, and their negligence of the pending threats of abandoning religious belief should be questioned and destabilized. 


\section{Works Cited}

Boxall, Peter. Don DeLillo: The Possibility of Fiction. London: Routledge, 2006.

Chandler, Aaron. "An Unsettling, Alternative Self: Benno Levin, Emmanual Levinas, and Don DeLillo's Cosmopolis." In Critique, vol. 50, Issue 3, (Spring 2009): 241- 260.

Conte, Josef. "Writing Amid the Ruins: 9/11andCosmopolis." The Cambridge Companion to Don DeLillo. (Ed.) John N. Duvall. Cambridge: Cambridge University Press, 2008: 179 - 192.

Crosthwaite, Paul. "Catastrophe Fiction in the Age of the Global Accident: Don DeLillo's Cosmopolis". The London Consortium Static. (July 2008): $1-13$.

DeLillo, Don. White Noise. New York: Penguin Books, 1985.

DeLillo, Don. "In the Ruins of the Future: Reflections on Terror and Loss in the

Shadow of September.” Harper's, (December 2001): 33- 40.

DeLillo, Don. Cosmopolis. London: Picador, 2003.

Donovan, Christopher. Postmodern Counternarratives: Irony and Audience in the Novels of Don DeLillo, Charles Johnson, and Tim O'Brien. London: Routledge, 2005.

Douglas, Christopher. "Don DeLillo.” Postmodernism: The Key Figures. Bertens, Hans \& Joseph Natoli (Eds.). Massachusetts \& Oxford: Blackwell, 2002: 104 - 109.

Elliott, Emory. "Terror, Aesthetics, and the Humanities in the Public Sphere." The Japanese Journal of American Studies, No. 19. (2008): 7- 23

Gartman, David. Auto Opium: A Social History of American Automobile Design. London: Routledge, 1994.

Gediman, Paul. "A Day in the life of the Present: Don DeLillo on Cosmopolis." Interview with Don DeLillo. Borders Web Site. Web. 25 Feb. 2011 http://www.bordersstores.com/features/feature.jsp?file=delillo $>$.

Hunsinger, Henry. "Heinrich's Hidden Prophesy: The Quest for Relevance in Don DeLillo's White Noise". Web. 13 March 2011 


\section{Nader Mostafa Helmy}

http://www.wilkes.edu/Include/academics/kirby\%20canon/TheQuest.pdf

Hurd, R. Wesley. "Postmodernism"

http://msc.gutenberg.edu/2001/02/postmodernism/

Kaplan, E. Ann Ed. "Introduction". In Postmodernism and Its Discontents. New York: Verso, (1988): 1- 9.

Kavadlo, Jesse. Don DeLillo: Balance at the Edge of Belief. New York: Peter Lang Publishing, 2004.

LeBesco, Kathleen. "White Noise as Wake-Up Call: Teaching DeLillo as Media

Skeptic." Approaches to Teaching DeLillo's White Noise. Eds. Tim Engles and John N. Duvall. New York: Modern Language Association of

America, (2006): 87- 101.

LeClair, Tom. In The Loop: Don DeLillo and the Systems Novel. Urbana \& Chicago: University of Illinois Press, 1987.

Lentricchia, Frank. "Introduction.” New Essays on White Noise. Lentricchia, Frank (Ed.) Cambridge: Cambridge University Press, (1991): 1- 14. Series: The American Novel. Ed: Emory Elliott.

Linardi, Silvia de Menezes. "All the World is a Screen: The Power of Media Simulacra in the Novels of Don DeLillo". Belo Horizonte, V. 6, (2003): 233- 243.

Miller, Laura. "The War for the Soul of Literature". Web. 13 Feb. 2011 http://www.salon.com/2004/07/15/peck_wood/

Noble, Stuart. "Don DeLillo and Society's Reorientation to Time and Space: An

Interpretation of Cosmopolis.” In AS Peers, Vol. 1. (2008): 61- 74.

Osteen, Mark. American Magic and Dread: Don DeLillo's Dialogue with Culture. Philadelphia: University of Pennsylvania Press, 2000.

Passaro, Vince. "Dangerous Don DeLillo." Conversations with Don DeLillo. Ed. Thomas DePietro. Jackson: University Press of Mississippi, 2005: 75- 85.

Rettberg, Scott. "American Simulacra: Don DeLillo's Fiction in Light of 
Postmodernism." Web. 12 March 2011

< http://www.cx.unibe.ch/ens/dellilo/whitenoise.index.htm >

Scarry, Elaine. The Body in Pain: The Making and Unmaking of the World. Oxford and New York: Oxford University Press, 1985.

Smith, Aaron. "Poetic Justice, Symmetry, and the Problem of the Postmodern in

Don DeLillo’s Cosmopolis." GRAAT, 7 January (2010): 238- 252.

Tabbi, Joseph. "Cognitive Fictions." Series: Electronic Mediations volume 8. Eds. Hayles, Katherine; Poster, Mark \& Samuel Weber. Minneapolis \& London: University of Minnesota Press, 2002.

Tew, Philip. "A New Sense of Reality? A New Sense of the Text? Exploring Meta-Realism and the Literary-Critical Field." Beyond Postmodernism:

Reassessments in Literature, Theory, and Culture. Ed. Klaus Stiersdorfer.

Berlin: deGruyter, 2003: 29- 49.

Waugh, Patricia. Feminine Fictions: Revisiting the Postmodern. New York: Methuen, 1989.

"What is Hypochondria?" Web. 10 April 2011. www.medicalnewstoday.com/articles/9983.php -

Wilson, Louise. "Cyberwar, God and Television: An Interview with Paul Virilio." Digital Delirium. Eds. Arthur and Marie Louise Kroker. Montreal: New World Perspectives, 1997: 41-48.

Wood, James. "Human, All Too Inhuman". The New Republic 223(4). July $17^{\text {th }} 2000: 41-45$. 